\title{
Alter-ontologies: Towards a constituent politics in technoscience
}

Dimitris Papadopoulos

University of Leicester

\section{Contact author:}

Dimitris Papadopoulos, School of Management, University of Leicester, Ken Edwards Building, Leicester LE1 7RH, UK. Email: papadopoulosd@ cardiff.ac.uk

\begin{abstract}
This paper identifies four recent conceptualisations of politics in relation to technoscience, which focus on expertise, institutional participation, the inclusion of non-human others, and the importance of marginalised experiences. The paper argues that each of these forms of politics is mainly concerned with renegotiating the already constituted terms of inclusion in a specific technoscientific field. While in many cases such a strategy is necessary, the paper aims to open up discussion of alternative forms of politics that act as constituent forces of radical social and material transformation in technoscience: alter-ontologies.
\end{abstract}

\section{Keywords}

alter-ontology, assembly, constituent politics, expertise, objectivity, participation, situated knowledges, technoscience

Attempts to find definite descriptions of the connection between technoscience and politics are usually prone to reductionism and oversimplification. The traditional way in philosophy of science to think of this relation was epistemology, where the content of technoscience and the associated politics were subordinated to ways of knowing and defining truth (Alcoff, 1998). Social studies of science emerging in the 1970s contested this view, but their attempts to question traditional epistemology devolved into a new cycle of epistemological disputes between proponents of rationality and sociality (Longino, 2002). These debates will be briefly discussed later in this paper. My argument here is that epistemology is less useful as a tool for discerning and navigating through the intricacies of scientific knowledge/politics than as a tool for reproducing them by other means. The covert politics of epistemology culminated in provoking the science wars of the 1990s.

The response to these heated debates in science and technology studies (STS) was an attempt to exit epistemology altogether. Furthermore, there is an increasing tendency to consider science together with technological and other applications -- as technoscience or in the words of Jerome Ravetz (2006) post-normal science. These changes led to a new understanding of objectivity; one that limits its validity in time and space to a certain field but nevertheless recognizes that technoscientific knowledge holds objective status within that 
field. That is, knowledge is shaped by the actual process of technoscientific research and its objects and simultaneously shapes social relations and material arrangements in each particular field. Here, I use the expression 'regions of objectivity' to refer to the ultimate horizon against which any question about politics in technoscience can be discussed. In the sections that follow, I will discuss four current conceptualizations of how politics is considered to be operative in a region of objectivity. I start with a formalist approach to politics, which is mainly concerned with rethinking expertise and creating the appropriate procedures for considering legitimate experts in a debate. A second approach to politics, participatory politics, is concerned with the expansion of the limits of public deliberation in a region of objectivity. The third approach focuses on the extension of our understanding of politics beyond human actors. A fourth emerges when actors who have been hitherto neglected in a region of objectivity contest existing knowledge and restructure the conditions of scientific knowledge production from the standpoint of their experience.

Not only do all these approaches attempt to conceptualize different types of politics in a region of objectivity, but they also are directly or indirectly influenced by existing forms of political practice beyond the realm of technoscience. I will draw upon resources stemming from political theory, social theory and actual political practice that inform the understanding of these four approaches. This leads to the final section of the paper, which attempts to open up debate on a form of politics which seems to be less visible in prevalent approaches to technoscience: I call this alter-ontological politics, in reference to the practices of new social actors emerging in the wake of the alter-globalization movements in the past ten years. The main concern of these politics is to create different forms of knowledge production that act as constituent forces of political change: forces aiming to craft alternative regions of objectivity.

\section{Exit from epistemology: Regions of objectivity}

Constructivist positions emerging within the field of the social studies of science and technology, starting in the1970s and '80s asserted that scientific knowledge is genuinely social and political: depending on values, interests, ideologies, and resources available to the researcher in the laboratory or in the field. This view was fiercely disputed by proponents of objectivist positions who argued that knowledge is a cognitive achievement emerging out of the application of rational criteria for evaluating salient phenomena of the social or natural world. In a strange way, both positions are somehow relevant and neither of them is quite true 
on its own: there is always a social and political context shaping the design and outcomes of research, and there is always relative autonomy to the intrinsic rules and material constraints that govern how research takes place. So, if the distinction between constructivism and objectivism does not hold (at least in the way often supposed), why was it conceived as a problem that dominated the debates over the nature of knowledge production for almost twenty years? A likely answer is that these debates served as instruments for changing the contents of knowledge. Rather than illuminating how knowledge is produced, they served as means by which scientific and social scientific knowledge itself was contested or consolidated.

The constructivism-objectivism debates tried to establish zones of contention in the middle of a relatively stable unfolding of science and social science. Epistemological discussions became an integral part of the everyday functioning of the fabrication of knowledge. Even if epistemology is a poor way to understand how knowledge is manufactured, objectivist and constructivist arguments serve as an exceptional tool that can be used to challenge the very content of knowledge. Epistemological disputes are usually developed by specialists (for example social studies of science scholars or philosophers of science) but the discourses themselves are implicated in the production of science itself. Like the controversy between Boyle and Hobbes, contemporary scientific dispute are fought also on the ground of what counts as truth, and not only on the success of particular experiments. The debate about ideology in the natural and life sciences coming from the radical science movement was not just about politics, truth and ideology but had implications for the construction of knowledge itself, for example in strengthening the critical voices against genetic reductionism in biology. We could conclude from such debates that epistemology neither shapes scientific knowledge directly nor is a completely independent discourse hovering above the 'real' scientists themselves. Epistemology is an active force -- one of many and probably not the most important -- in the making of scientific knowledge. The question of evidence (scientific and social scientific research) and the epistemology of evidence (epistemological debates in each particular scientific field, philosophy of science and social studies of science and technology) are both located in the same economy of knowledge production. Epistemology is not about scientific research, it is its continuation.

Following the science wars of the 1990s there seems to be a departure from epistemology as a detached observation of science, and a subsequent turn to consider epistemological debates as part of the broader conditions of knowledge production. Scientists and their research -- the organisms, things or populations under study; technological 
apparatuses, methodological instruments and epistemological debates; ethical beliefs, cultural imaginaries and the wider polity; interest groups and state authorities; transnational institutions and national funding bodies -- all are players in the same game. They exist in same social/ontological field and their co-actions establish spaces in which certain ways of thinking and acting, and the very materiality of their existence, appear as given, or, if you like, as matters of fact. In this paper, I shall call such an integrated field a region of objectivity. This type of objectivity is very different from the objectivity that dominated the debates of the 1980s and earlier, as the undistorted representation of the logic of things. As we exit epistemology and enter into zones of contention, a different conception of objectivity appears to be emerging, as knowledge now seems to be objective in a certain field to the extent that it manages to thoroughly transform the material conditions of existence in that field. It is objective to the extent that different actors in the field manage to object, transform and remake the process of knowledge production itself. Thus, being objective is no longer considered to be an abstract qualifying attribute of knowledge, but refers instead to the efficacy of knowledge practices to transform the materiality of existence.

Desires, hopes and investments in the objects under study -- be they individuals, social groups, animals or things -- mingle with the constraints these objects impose on the researcher, as well as with interest groups, ethics and beliefs, affected social actors, and state institutions. Together, they produce knowledge in ways that inexorably transform the immediate ontological composition of a region of objectivity. The main question for my argument is: What holds together a region of objectivity and organises the internal relations between the multiplicity of actors involved, if we know already that organizing agency is not limited to social interests or other external factors, scientific authority itself, or some hidden epistemological foundation? I would argue that it is a form of politics, but what kind of politics? There is something paradoxical here: the stronger and more stable a region of objectivity, the stronger the impression that politics has been expelled from it. Nevertheless we also know that the stronger a region of objectivity is, the more it relies on some sort of politics that regulates collective relatedness in order to attain and maintain its (relative) stability. What is the particular type of politics we perform in a region of objectivity? What is this form of politics and how does it differ from and relate to other forms of polity? That is, what is the politics of knowledge when it is not about epistemology, but about the making and remaking of regions of objectivity? In the following sections, I approach four distinctive answers to these questions. 


\section{Formalist politics and the liberal predicament}

One approach to how a region of objectivity is constituted and regulated is to illuminate how legitimacy is conferred to participate in a debate over a technoscientific issue. This is a prescriptive approach to technoscience and politics, which tries to demarcate expertise and deploy a formal structure to resolve technoscientific controversies. It is thus an exercise in formalist politics. The starting point is a classification of different types of expertise that are necessary for shaping public discourse and decision-making (Collins and Evans, 2007). In the Collins and Evans version, the formalist approach focuses mainly on identifying different forms of expertise beyond 'contributory' expertise (that is the highest level of expertise possessed by active practitioners who have a level of skill and knowledge allowing them to participate fully in their scientific field and to contribute substantially to its development).

Here, the inclusion of legitimate experts (and subsequently the exclusion of nonlegitimate experts) in a formalised process of deliberation over a technoscientific controversy is seen as the main way to reshape the relations between different actors in a region of objectivity. Crucial in this process is then to extend expertise in a regulated way by using certain standards for identifying actors who can express valuable opinions about relevant technical aspects in a controversial issue (for examples, see Edwards and Sheptycki, 2009; Weinel, 2007). From the perspective of formalist politics there is a technical phase and a political phase in every technoscientific issue: technical decisions should be left to experts and experts should try to avoid influences from the broader cultural and political environment (Collins and Evans, 2007: 8-9; Collins, et al., forthcoming). This distinction between technical and political phases challenges the social constructionist enterprise, as discussed earlier. Instead of focusing on how extra-scientific factors influence the production of knowledge (the so called political phase), the formalist approach tries to find out how intrascientific factors can be meaningfully regulated. This may seem like a response by social constructivists to the science wars of the 1990s, and it is indeed a way to preserve the relative autonomy and specificity of scientific knowledge. Social constructivism becomes Weberian, but with a twist or two: not only can the credentialed 'contributory experts' make a difference in the technical phase of debate, but so can other potential experts who lack contributory skills but hold potentially important knowledge on particular topics in virtue of their experience. However, this is not a trick used in the wake of the science wars to appease scientists enraged with the debunking of their specific expertise by social constructionists. 
Rather, it is an attempt to preserve the specificity of scientific knowledge production while also opening it up to contributors who had not been acknowledged previously.

The formalist approach simultaneously opens and closes the process of knowledge production. It opens the process of legitimacy by not restricting it to contributory experts, but it closes it down again when the process of scientific knowledge production is about to implode through the introduction of extra-scientific interests. The opening is performed by assigning expertise to social actors who possess relevant knowledge without being traditionally recognised as contributory experts. Collins and Evans (2007: Ch. 3) call this crucial type of expertise interactional, which allows affected social groups with sufficient experience and knowledge to participate in a debate over a specific controversy. However, they also exclude other types of knowledge, such as general popular understanding or knowledge extracted from primary sources without deeper immersion (Collins and Evans, 2007: Ch. 1). This inclusion and exclusion of different expertises attempts to define and preserve the borders of what counts as legitimate expert participation in a region of objectivity. In fact, the formalist approach is about policing these borders, rather than offering substantial sociological or other insights into any particular scientific controversy.

The formalist approach addresses the question of politics not in a substantive way, but by defining rights of participation and inclusion. It does not formulate a core set of guiding issues which can be used to resolve a controversy or a debate. Rather it attempts to provide a framework for regulating how to approach a technical issue. An underlying assumption of the approach is the necessity of basic agreement on the normative principles that govern the deliberation process, and so its point of departure is contractualism (Rawls, 1971). Formalist politics ask what circumstances should be appropriate for resolving a technoscientific controversy, and what principles of deliberation should people reasonably embrace in order to achieve resolution. That is, it tries to set out rules according to which all legitimate participants offer reasons for or against certain arguments; rules that need to be followed in unforced communications in which all participants act reasonably, and are well-informed (Habermas, 1993; Scanlon, 1998). According to the formalist approach, such principles are negated when extra-scientific politics enter into the technical phase of a debate and dilute expert negotiations. This logic is akin to the centrality experts play in contemporary liberal democratic political ontology (Turner, 2003), in which well-informed representatives and experts are assumed to settle disputes in terms of fundamental rules based on principles that protect everyone: a constitution that regulates the process of decision making. 
However, there is a crucial complication with the formalist approach: the structures that can be used to facilitate informed and democratic deliberation over a particular controversy are already permeated by the controversy itself. The political architecture that creates the possibility for resolving the controversy does not exist prior to the controversy itself. The crux of formalist politics -- the possibility of constituting a flawless space as a starting point for communication between the participants in the social contract -- is an untenable position when viewed in real historical perspective. Such a space is never a given or actual starting point. One can argue that this presents an even stronger argument for the formalist approach: the more such spaces of communication elude us the more they are necessary, the more they are necessary the more we should accept them as a paramount value (what Collins calls 'elective modernism'). However, elevating formal-regulative principles to core values does little other than to invoke an authoritative moral code; it does not make them work in reality. Formalist politics occupy the space of the normative by vacating the space of the actual.

Like any other version of formal-regulative ethics of political engagement (see for example Habermas, 1984), formalist politics in science and technology miss the substantial embeddedness of structures of communication in the deeply asymmetrical and unequal social, cultural and historical grammars that traverse the structures themselves (Wellmer, 1977; Taylor, 1986). Formalist politics thus miss the fact that controversies emerge, not because a proper process of expert deliberation has not (yet) taken place, but because it already has failed somewhere along the way. The formalist approach is good at illustrating, in retrospect, how such failure takes place. However, a historical moment in which science and technology increasingly fold into each other, demanding that actors behave as though they could invoke a separate and pure technical phase, becomes untenable. In fact, what the formalist approach is good at detecting is the stratified and unequal contributions that each participant can make. What it cannot do is to engage with them in a real and processual fashion. Formalist politics occupy the space of observation by missing the space of transformation.

It is, of course, the case that formal rules sometimes can instigate social transformation in a region of objectivity. When rules of negotiation are derived from the particular conditions of a controversy they can have transformative effects. When viewed from an historical political perspective, such rules are always the target of social movements that contest the formal structures of liberal democracies by demanding radical changes in the norms and legislation governing social reality (for example, the civil rights movement, the women's movement, the gay rights movement), but this kind of understanding is exactly what 
the formalist approach denies. Formalist politics are literally formal: the rules are not derived from a certain situation or controversy; instead, the same rules are assumed to apply to every technoscientific controversy. Formalist politics -- in a truly Habermasian fashion (see Wimmer, 1980) -- attempt to operate as a transcendental judge in order to control procedures for deliberating over the controversy. This external universalising position can only function as an adjustment within the constituted order in a certain region of objectivity. Despite its heuristic function and democratic flair, the formalist approach cannot act as constituent force that remakes, not only the rules for debate, but also its very content and scope. Formalist politics perpetuate the given constituted order because they fail to engage with effective ways for intervening in the actual circumstances of a controversy.

\section{Participatory politics and the limits of institutions}

A second approach to conceiving politics in a region of objectivity focuses on the conditions of participation and the processes through which lay people are included in debates over scientific research. The participatory approach does not start from a 'normative' or 'formalist' definition of who has the necessary expertise to be included in the deliberation process. Instead, it makes a structural claim about the inclusive conditions for shaping science and technology (Lengwiler, 2008). This approach thus focuses on three aspects of participatory politics: Who needs to be included? Where and when is participation needed? How can we enhance participation; what specific processes need to be considered?

The broad answer to the 'who?' question usually attempts to develop insight into how to facilitate the co-constructive role of the public for shaping technological objects and scientific practices. It attempts to go beyond seeing the public as an influence on applications and social consequences of science (Wynne, 2005; Irwin and Michael, 2003; Leach et al., 2005). The public is a highly elusive and easily instrumentalised category, however. Attempts to concretise the public mainly include stakeholders such as NGOs, affected social groups (usually self-organised), or other Civil Society Organisations into the process of decision making. They tend to emphasize user groups, patient groups, and activist groups that organize themselves to articulate specific claims on existing technologies (for examples see Callon and Rabeharisoa, 2008; Elliott et al., 2010; Epstein, 1996; Felt et al., 2008). This particular form of inclusion has its roots in the women's health movement (Hubbard et al., 1979) and feminist approaches to medicine (Clarke and Olesen, 1998; Rapp, 2000), organizations of people 
living with HIV and AIDS (Epstein, 1995), as well as environmental health movements (Brown, 2007). Facilitating the participation of such groups can be strengthened by changing broader scientific research agendas themselves or more specific science policies. For example there are calls to intervene in science 'upstream' (Wynne, 2003), before applications are decided and when it is still possible to shape the compilation of research agendas. Science policy has received particular attention in science and technology studies as well as the investigation of active interventions in the policies for governing science (Chilvers, 2008; Jasanoff, 2003; Rowe and Frewer, 2004; Webster, 2007).

The question of 'where?' often appears in close connection to the problem of 'how?': we find approaches that call for practices that invigorate advocacy (Fortun, 2001), public engagement (Elliott and Williams, 2008) and that reinforce the conditions of possibility for accountability (Munro and Mouritsen, 1997; Neyland and Woolgar, 2002). There are also broader quests for a civic epistemology and the setting up of an agora as space for negotiation between scientific and social actors (Nowotny et al., 2001) as well as accounts that strive to enhance inclusive procedures in decision making (Liberatore and Funtowicz, 2003) and deliberation (Davies, 2006).

Participatory politics in all their variety and nuance shift the focus from who is an expert or who is a legitimate participant in a region of objectivity to the problem of enhancing inclusion of lay citizens, and in certain cases to the issue of becoming expert. They are thus concerned with changing the very structures in which debate in a region of objectivity takes place. Participatory politics differ significantly in their scope, target, tactics and radicalism. In this paper when I refer to participatory politics I mean approaches that aim to reform existing institutions in order to change the conditions of citizens' inclusion. Of course, there are more radical approaches that go so far as to question the whole institutional structure and propose a radical democratic approach to creating grassroots initiatives, or even alternative institutions. Some of these more radical democratic positions will be discussed later, as part of the grounded approaches that highlight the importance of power inequalities in society and their effects on the shaping of science and technology. The form of participatory politics that I discuss here is more central to STS, which are mainly concerned with the role of social difference in science policy and with invigorating public participation (Epstein, 2007). Deliberative democracy, policy adjustments and public accountability become the tactical means deployed in participatory politics to promote inclusion that changes the balance of knowledge/power in a region of objectivity. 
The public in participatory approaches is imagined to be civil society -- one of the most empty and vague categories in social and political theory. This concept of the public tends to homogenise people beyond the main participants in a debate -- it can be a whole nation, the inhabitants of a certain region or city, or an affected group of people by a certain technology or scientific application. In a sense, this 'outside' public is constructed by the 'inside' actors who define the terms of the debate. However vague and opportunistic, this concept of the public performs an important function for the balance of power in a region of objectivity: it acts as an avatar of civil society. The civic imperative of participatory politics is to construct regions of objectivity such that civil society can be included in processes of direct democratic decision-making. Civil society in participatory approaches refers to actors who come together on a voluntary basis rather than as functions of state-supported institutions such as education and science, or pure market forces. Civil society is seen as a counterbalance to both strong individualising tendencies of liberal democracies that emphasise the single person as well as to the excessive growth of particular state functions and governmental institutions. Instead of focusing on abstract and formal procedures for settling technoscientific controversies, participatory politics emphasise that sound science policy can only be achieved if there is a system in place that relies on citizen deliberation and engagement.

There is here a strong echo of communitarian positions (Taylor, 1991; MacIntyre, 1981), which portray a 'community' whose members negotiate specific issues in terms of their 'horizons of meaning'. In participatory politics, the public is comprised of social groups and communities who deliberate over a common good against the background of a shared horizon of practice and meaning. Participatory politics works on the interface between the community and existing institutional structures. Institutional spaces guarantee the broadening or narrowing of the accepted horizons of meaning against which a controversy in a region of objectivity can be debated and eventually resolved.

The keyword here is framing: appropriate framing of an issue in order to include public actors. Framing in this context is not a pure discursive strategy (Leach et al., 2005); rather it refers to real social spaces that enable alternative ways to frame an issue. However, the questions of how far and how many actors can be included in the deliberative processes of an institution is always filtered through the existing possibilities and margins that the institution allows -- in Neyland and Woolgar's (2002: 272) words the 'conditions of possibility for accountability'. Participatory politics -- and here I refer to the mainstream of participatory approaches, not to radical forms of participation which will be discussed below 
-- operate as corrective forces to the shortcomings of existing institutions. It is not the institutions that are seen from the perspective of the public but the public that is seen from the perspective of the institution. Transforming existing institutions can, of course, have far reaching effects in democratising a region of objectivity. Nevertheless the limitation remains that the public is indeed a plastic category that shrinks or extends to include the stakeholders who can be included in a given institutional structure. Participation of this kind operates in an already constituted field of existing institutional coordinates which not only define a certain problem but also its potential participants. As such it has far reaching consequences but does not provide for a form of constituent politics that not only transforms existing institutions but also has the capacity to operate, if necessary, outside existing institutions and to give birth to alternative forms of action, imagination and reasoning in a region of objectivity.

\section{Assembly politics and the ignorance of governance}

If participatory politics focuses on the inclusion of social actors in existing political institutions, Actor Network Theory (ANT) attempts to include non-humans in descriptions and ways of acting in a region of objectivity. ANT avoids thinking in terms of the sociopolitical and the natural as divided worlds. In accordance with Whitehead's diagnosis of the bifurcation of nature, ANT has questioned the split between science and the humanities/social sciences. It proposes a reassembling of the social that complicates this bifurcation and prevents us from 'counting in advance' what comprises society and nature (Latour, 1993).

Dingpolitik according to Latour (2005b) -- and here we also can think of other ANT theorists (e.g. Mol, 2002; Law, 2004; Callon, 1987) -- is a way to explore how humans and nonhumans collectively and in an emergent way make meaning out of an issue by being implicated in networks of connectivity.

Thus the main concern is to describe these connections, and to elucidate the appropriate assembly for dealing with particular issues: 'Every new non-human entity brought into connection with humans modifies the collective and forces everyone to redefine all the various cosmograms' (Latour, 2007: 813). Cosmograms are divergent and often conflicting ways of actual world-making. Latour argues that the task of STS is to 'detect how many participants are gathered in a thing to make it exist and to maintain its existence' (Latour, 2004: 246; see also Stengers, 2005). Latour and other ANT theorists therefore also propose a formalist approach, albeit quite different from that described earlier: to define the appropriate staging for each problem, so as to enable effective processes of representation, mediation and 
translation between human and non-human actors. In order to accomplish this, it is necessary to maintain symmetry between the different actants and explanations, since a hasty conclusion about a prevalent form of agency can trap us into 'prematurely naturalized objectified facts' (Latour, 2004: 227). Attention to symmetry reveals how new entities are formed in the socio-material world and how new complex 'entanglements' (Callon and Rabeharisoa, 2004) of mutual attachments involve different actors and things.

The central political theme reverberating through the assembly approach is a strong anti-foundationalism, in particular a critique of the split between society and non-human others, whereby 'society' and its organizational principles are given primacy over the nonhuman in other STS accounts. This anti-foundationalism is situated in the broader context of fashionable object-oriented theories concerned with issues of diffused power, hybridity, emergence, and open architectures of networks. Anti-foundationalism of this kind rests on the assumption that a given entity is an effect: it is made through its connections with other things: 'Actor-network is, has been, a semiotic machine for waging war on essential differences' (Law, 1999: 7). What exists is produced and made through relations: 'relations everywhere' (Strathern, 2005: 37).

This focus on relations and connections, I want to argue, corresponds to a broader shift in thinking about politics as governance in contemporary political theory and practice: politics as an affair of actants perpetually adapting to, and establishing alliances and networks with, others. This conceptualisation of the political implicitly critiques the governmentality model that has dominated socio-political theory in recent decades (e.g. Barry et al., 1996). Instead of self-activating actors and processes of subjectivation, that is instead of conceiving the production of subjectivities as an effect of power, governance is a form of a-subjective management which emerges through connecting actors and creating alignments between them.

Governance has increasingly become a dominant trope of political thought and practice (Rosenau and Czempiel, 1992; Rhodes, 1997). Governance signifies the erosion of constitutionalism as an established set of generally accepted principles in sovereign law. It is post-constitutionalist, that is, in a scene populated by many different interconnected and partial actors, governance offers a common mode of effective political stability and functioning (for example: Bevir and Rhodes, 2003; Edwards and Hughes, 2005; EC Commission, 2001). In other words, the polity is not made possible by following predefined or abstract principles imposed by a central authority (usually the nation-state). Rather, governance today describes the process that regulates the search for regulating principles, in 
the absence of an authority which guarantees such principles. Regulating principles are developed ad hoc through intensive negotiation between participating actants. In the language of ANT this is an assembly. The important contribution of assembly politics is that it elucidates the existence of, and the connections between, human as well as non-human actors which are necessary for sustaining a region of objectivity.

However, governance is not an innocent form of political organisation and management, it is related to an overarching form of production predominant in contemporary Western societies (Harney, 2006). It is a mode which renders the actants and entities participating in a region of objectivity productive, in a double sense: First, politically productive and, second, active participants in the existing mode of production. Regarding the first: there is a preoccupation in ANT with discerning how a situation comes into being, how complex assemblages evolve through the relational actions of the participating actants. This is the political side of assembly politics: it necessitates the creation of new political forums which accommodate the emerging constellations between human and non-human others. However, the insertion into the political assembly happens in correspondence with the incorporation of these entities into a new mode of production. Assembly here refers to its other meaning, the assembly plant, yet this is not the linear assembly line of the Fordist factory, but the self-valorising assembly system of the Post-Fordist economy. This economy is characterised by deindustrialisation, the rise of services and immaterial work in the Global North, the global precarisation of employment relations, flexible and lean production architectures and the neoliberal dismantling of social provision (see for example Panzieri et al., 1976; Marazzi, 1998; Gorz, 1999).

Thinking politics in a region of objectivity in terms of governance goes hand in hand with the emergence of new forms of displacement. The assembly, as the space for negotiation and governance, is not just a descriptive category for practices in the current polity. Rather, it resolves certain limitations and antinomies of the existing order and at the same time installs new forms of social and material control. The point here is not about good or bad governance, but about how governance as such is the very political algorithm of contemporary structures of power. Various positions question the effects of governance and the underlying logic of productionism (Papadopoulos et al., 2008; Haraway, 1992b; Negri, 2005; Harney, 2008). What is common to all of them is that they highlight the proliferation of injustice towards those who cannot or are not willing to contribute to the spaces that are regulated through governance. The assembly, as the space where governance is executed, is all-inclusive apart from those who do not or cannot express themselves in the required language -- let alone 
those who are unwilling to contribute to production or, even worse, who undermine the assembly with alternative political actions.

Latour (2004) envisions the assembly as a new possibility for political action that goes beyond politics as 'debunking'. An emphasis within STS on debunking, understood as the search for hidden causes behind people's actions, was responsible for igniting a strong antagonism from scientists (who supposedly neither know the sources nor the effects of the knowledge they produce). Social constructivism is probably the most powerful 'debunking' device in STS: it seeks to unravel the secret and invisible life of scientists' practices. The science wars were in fact a response to this understanding of science. Against the oldfashioned debunker, Latour proposes the 'new critic', someone who assembles, who is visionary, chic, slick, witty and effective, the spokesperson of the region of objectivity, somebody who smoothes the way of the participants into the new assembly.

However, this new critic resembles the prototypical inhabitant of the productionist regime of the Global North after the rise in the past twenty years of governance and the consolidation of neoliberalism. For Latour, the ultimate political question is: '[c]an fundamentalism be undone?' (Latour, 2005a: 31; see also Latour, 2003: 28). In other words how can we ignore or attenuate the effect of all these actors who disrupt the assembly of governance with an intractable conviction about justice, who ask inappropriate questions, who position themselves outside the 'we' of the assembly, who create alternative spaces and bring the wrong messages? 'If you cannot bring good news, then don't bring any' is ANT's answer. Ignore the troublemakers, ignore otherness which is incompatible. From the point of view I am developing in this paper it is necessary to betray the constituted order of governance in order to allow for a really self-organised assembly to take place, such as the radical democratic social and ecological movements since the end of the 1990s have shown so clearly (Chesters and Welsh, 2006; Papadopoulos et al., 2008). Assembly politics offers an important insight into the intricacies of a region of objectivity by enlarging our understanding of material agency, but ultimately these new forms of agency are reinserted into the constituted form of polity.

\section{Grounded politics and the indeterminacy of experience}

Haraway's (1988) proposal for a situated view of technoscientific knowledge signifies a very different starting point for conceiving politics in a region of objectivity. Instead of thinking 
that a region of objectivity is an already constituted field, a situated perspective identifies with the neglected experiences that certain participants in a region of objectivity enunciate (also see Star, 1991). This line of knowledge politics initially arose within feminist standpoint theory. It engages with different marginalised standpoints in a context of structural relations of power (e.g. Rose, 1994; Harding, 1991; Hartsock, 1983). This approach to knowledge politics attempts to understand how knowledge is situated and grounded in the real conditions of conflicting existences in a region of objectivity. It is the very process of approaching knowledge as a grounded endeavour that valorises neglected experiences as 'oppositional' knowledge (Sandoval, 1991). One of the avenues that standpoint theory opens is the insistence that the 'we' so often assumed or summoned in all previous approaches does not exist (the contractualist we, the possibility of all-inclusive institutions or the we of the assembly). Of course, recognised experts, policy-makers, law-makers, facilitators, observers, or mediators are all necessary instances in creating the political architectures of a region of objectivity, but from the perspective of grounded politics the most crucial viewpoint is that of a fully engaged yet partial participant in a real socio-material configuration. This is the reason why I call this approach grounded: grounded in actual social and material modes of being and taking into account that every attempt to contest or change them, every possible line of flight, has, as its starting point, situatedness in a concrete ecology of existence.

Politics in this grounded approach ensues because every engagement with science and technology is arranged across asymmetrical positions. While other approaches attempt to avoid asymmetry altogether (the assembly approach), or locate asymmetry in the quality of our knowledge (the formalist approach) or in the access to structural institutional functions (the participatory approach), the grounded approach sees asymmetrical relations as constitutive of the very conditions that produce science and technology in a region of objectivity. Thus we see stronger critiques of how technoscience contributes to domination (Winner, 1993; Feenberg, 1991) or louder calls for a deep change of the social and political structures that facilitate radical forms of intervention (Figueroa and Harding, 2003; Shiva, 2006). Finally, attention is drawn to mobilisations of radical science movements (Nowotny and Rose, 1979; Rose and Rose, 1969; Ravetz, 1990) and radical democratic participation and science activism (Woodhouse et al., 2002; Hess, 2007b). Many of these positions are reflecting radical critiques of technological, scientific and medical rationalities (e.g. Illich, 1979; Marcuse, 1991; for a discussion see Feenberg, 1995) and are historically rooted in the social movements of 1960s and 1970s -- in particular feminist, antiwar and antinuclear and ecological movements and the new social movements after the 1990s (Hess, 2007a, 2004; 
Welsh et al., 2007). It is no coincidence that standpoint theory, which marked an important historical moment in the development of grounded politics, resonates strongly with a Marxist view of social organisation. Existing institutions (as in the participatory approach), calibrated and standardised procedures (as in the formalist approach), or spaces of inclusion (as in the assembly approach) are facets of a continuous movement of social transformation that is primarily initiated by neglected, silenced or effaced positions in an asymmetrical and thus antagonistic social order.

Yet the grounded approach also opens up a post-Marxist reading of social transformation when it refuses to reduce all the contradictions in a region of objectivity to the totalizing social dichotomy and dialectical struggle emanating from one underlying antagonism (usually conceived as the antagonism between capital and labour). Here there is no monolithic totalising structure that determines the existence of marginalized positions (Marcuse, 1991), it is rather a decentered and multifaceted structure of injustice that produces a range of different positions. This understanding of marginalised positions is supported by the rejection of a unified reading of the composition of oppositional experience. Instead, there is a focus on how different autonomous 'subaltern' social groups -- black people, migrant workers, women, new segments of the working class which could not be easily subsumed to factory workers -- develop divergent self-organised experiences which do not simply reflect the main social antagonisms but diffract them into new forms of social existence (Malos, 1980; Moulier Boutang, 1998; Negri, 2005; Papadopoulos et al., 2008).

However there is an important question which has to be asked in relation to the very nature of the groups, human and non-human, which are effaced in a region of objectivity: Can their experience -- which is positioned as a more authentic form of objectivity (Harding, 1986) -- be treated as given and definite? Does the experience of the excluded pre-exist the relation of exclusion? While the formalist and participatory approaches seem to take experience for granted (as a 'have' or 'have not' feature of an individual actor), the assembly approach complicates the problem of experience by refuting its primacy altogether. Experience seems to be either reified as a substance or eliminated and dissolved in pure connectivity (for an extended discussion see Papadopoulos and Stephenson, 2007). This impasse between reification and dissolution also pertains to early positions in the grounded approach to politics. The problem here lies in a paradox for performing politics that starts from the assumption that situatedness in an asymmetrical world matters. If experience is reduced to a mere reflection of the immediate given position of the actor in power inequalities, it is also reduced to something that is instantaneously accessible and transparent. 
It is this move that undercuts any possibility for real transformation of the actors themselves because they are ultimately captured in an endless process of reiterating their own experience. This move underpinned identity politics during the post-war period in the Global North. Although cultural studies have vividly shown that identity is always in process, because it entails the remaking of the actors themselves and their social relations (Clifford, 2000; Hall, 1990; Papadopoulos, 2006), the 1990s marked a moment at which identity politics became increasingly unable to contribute to radical political mobilisations. Poststructuralism attempted to resolve this problem by introducing an idea of experience as discursive formation (e.g. Scott, 1991). This consists of two parallel endeavours: it challenges both the individualistic fallacy invoked in much talk of experience, and the notion that experience is a monolithic and transparent object of knowledge. However, this important critique of experience usually goes hand in hand with a reduction of experience to a mere sociohistorical incident that undercuts any possibility for agency and introduces a disembodied form of social relationality and existence (Stephenson, 2003).

Can grounded politics challenge the pervasive logic that sees experience trapped in the binary logic between reductionist essentialism on the one hand and discursive antifoundationalism on the other? Is it possible to question both the reification of experience in earlier accounts of grounded politics as well as the elimination of experience through the thinking of governance, assemblies and discourse? The answer is yes, if experience is understood as something which is simultaneously constructed in the process of knowledge politics and yet powerful enough to craft alternative worlds that challenge a given region of objectivity. The crucial move here is that actors do not already have experience, they make it as they collectively contest existing forms of injustice. Experience in this sense evades representation: represent yourself and your experience (reification of experience in essentialist positions) or study the representations of experience in discourse (dissolution of experience in anti-foundationalism). Thus, the processual and collectively constructed understanding of experience that I am arguing for here becomes a retreat from the self, from clichéd subject positions, from the oppressive reduction of experience to the discourses prevailing in a certain context. Experience becomes a process that pushes itself to change (Whitehead, 1979). Experience is all there is (for an extended discussion, see Stephenson and Papadopoulos, 2006).

The point of departure for grounded politics is how experience of the involved human and non-human actors is collectively produced. The involved actors experience the world by making it, in a process where radical divergences between participants are negotiated and 
these negotiations constitute the processes of social and ecological world making (Haraway, 1992a). Many new social movements -- probably first and foremost the alter-globalisation movement and radical ecological movements -- rely on non-representational understandings of experience that do not connect participants on the basis of shared subject-positions or experiences, but on the basis of creating common spaces that afford negotiation of the radical divergences between them and allow for common action. This politics contests formalist approaches (whether in the form of the inclusion of experts or of governance) as well as approaches which limit participation to an institutional endeavour. From the perspective of grounded politics the point is not to create the correct assembly or institution but to engage with the dividing forms of power that count -- whether we like it or not -- for the practice of existing radical divergences in social, material and ecological environments (Haraway, 1988; Bracke and Puig de la Bellacasa, 2009; Stephenson and Papadopoulos, 2006).

\begin{tabular}{|l|l|l|l|l|}
\hline POLITICS & KEY & PROCESS & $\begin{array}{l}\text { POLITICAL } \\
\text { ONTOLOGY }\end{array}$ & CRUX \\
\hline \hline formalist & $\begin{array}{l}\text { normative } \\
\text { definition of } \\
\text { expertise }\end{array}$ & contractualism & $\begin{array}{l}\text { democratic } \\
\text { liberalism }\end{array}$ & $\begin{array}{l}\text { actual structures of } \\
\text { communication }\end{array}$ \\
\hline participatory & $\begin{array}{l}\text { deliberation and } \\
\text { inclusion of the } \\
\text { public }\end{array}$ & $\begin{array}{l}\text { invigoration of } \\
\text { civil society }\end{array}$ & communitarianism & $\begin{array}{l}\text { institutional } \\
\text { reductionism }\end{array}$ \\
\hline assembly & $\begin{array}{l}\text { anti- } \\
\text { foundationalism }\end{array}$ & $\begin{array}{l}\text { prodational } \\
\text { productionism }\end{array}$ & governance & ignorance \\
\hline grounded & situated action & $\begin{array}{l}\text { contentious } \\
\text { politics }\end{array}$ & $\begin{array}{l}\text { social and } \\
\text { ecological } \\
\text { antagonism }\end{array}$ & $\begin{array}{l}\text { formation of } \\
\text { experience }\end{array}$ \\
\hline
\end{tabular}

Table 1: Politics in technoscience

\section{Alter-ontologies: Constituent politics in technoscience}

Despite their significant differences and occasional disputes, all these approaches cast light on distinct aspects of the political in technoscience. In a peculiar way they all seem to complement each other. Perhaps this is the reason why a field as diverse as STS can be still considered a field, a region of objectivity in its own right. Winner's question '[d]o artefacts 
have politics?' is more than a crucial research question or an astute description of one of the first items on the agenda of a then-emerging field; it indicates the plane on which many of the issues in STS can be debated. Although the various approaches described in this paper occupy different positions on this plane, they remain within it and contribute to the development of the field by performing the very politics they try to describe. Perhaps a recurring theme in all these approaches is that they scrutinise the barriers of a region of objectivity: by broadening and codifying the limits of legitimate participants, the expansion and re-structuring of institutions, the inclusion of non-human actors, or the inclusion of neglected voices.

Technoscientific artefacts are indeed political phenomena. Every new technoscientific artefact resembles a legislative act that inaugurates a form of public order (Winner, 1986). What this paper asks is: if technoscientific things are legislative acts then how is it possible not only to develop a politics that illustrates and highlights the nature of these acts, but also contributes to their making? This is what is meant throughout this paper by constituent politics: a force that not only operates in the realm of the already constituted order but also reconstitutes a region of objectivity by developing language and skilled practices for the making of things: not how things are made, but how to make things with constituent political energies. The issue is therefore to develop a form of politics in technoscience that attempts to create alternative forms of life that primarily aim to make new socio-material realities rather than renegotiating the conditions of a given constituted order (as with formalist, participatory and assembly politics). I borrow the term forms of life from Winner (1986, especially Ch. 1), a term he traces back to Wittgenstein as well as to Marx. In forms of life we encounter a reweaving of the social and the material through the development of new practices and technologies. However, a practice or new technical device is not just used. It does not just enter into an existing organisation of life. Rather, a form of life is remade through it; a practice, a set of practices, a device, a new form of relationality becomes part of a form of life by changing it. Here I want to foreground a materialist reading of forms of life: they set up the very material constraints to what we are, how we act and what we can become: 'What has to be accepted, the given, is -- so one could say -- forms of life' (Wittgenstein, 1958: 226). I understand this as the making and sustaining of forms of life which have to be accepted because they transform the social and material order in ways that cannot be bypassed or neglected. Therefore, a form of life acts as a set of constraints against which actions as well as possibilities for new actions evolve and take place. It is in this sense that a form of life cannot be bypassed -- not because it defines in a deterministic fashion the outcome of actions 
(Smith and Marx, 1994), but because actions take place in the real space and time of a form of life.

The meaning of constituent politics in technoscience can be illustrated with the example of AIDS treatment activism in the 1980s. Epstein's (1995) description of how activists became recognized experts and increasingly contributed to shaping biomedical research can be re-interpreted as a form of constituent politics. Epstein describes a moment when a collective inserted itself into a biomedical region of objectivity in ways that undermined the existing terms and conditions of debate. He investigates how AIDS treatment activism, once it became powerful enough to enter existing institutions (such as the FDA drugs trial committees), changed the format of treatment research, clinical trial procedures and the distribution of medication,. In contrast, I am here interested in how AIDS activism became possible at all in order to be able to affect the changes Epstein describes. Epstein investigates the formation of AIDS activism in a somewhat teleological way: as something that targeted the inclusion of the movement's demands in committees and regulation. I want to read AIDS activism differently: as concrete, ordinary practical action that primarily targeted the making of justice in everyday life. Such remaking of the everyday led to the formation of new conditions of existence and action, which could not be ignored by existing institutions and public discourse. So, an approach is required that can account for the emergence of such actors long before any question about their inclusion is apparent. If one wishes to discuss constructivism (Stengers, 2008), then this would be a truly constructivist form of politics: the making of entities that change the conditions of possibility in a region of objectivity.

In retrospect, AIDS treatment activism has been analysed from the perspective of expertise and formalist politics; enhancing institutional participation; assembly politics, in terms of tracing the unpredictable entanglements of human (patients, activists, research, FDA regulators, etc.) and non-human (HIV virus, medications, tests for viral loads, circulating blood, etc.) actants; an actor which develops a voice based on the conditions of its exclusion. In this example however, I want to suggest a politics in technoscience that achieves all of this, but additionally and primarily participates in the very making of an actor that ultimately changed the very conditions of counting, perceiving, knowing, seeing and acting in the region of objectivity of HIV. It is exactly this kind of constituent politics that HIV treatment activists embarked upon in the early 1980s (Harrington, 2008; Bersani, 1987), long before their practices were codified as a form of politics (whether formalist, assembly or participatory). They reordered the conditions of everyday experience so as to facilitate the emergence of a 
new social actor, as well as the conditions in which questions could be posed anew (Stephenson and Papadopoulos, 2006). They created a whole new everyday lifeworld, by building organisations on the ground, renting and squatting spaces that facilitated a common culture, changing their sexual practices, fighting homophobia, sharing non-available medication in illegal clubs, re-appropriating biomedical knowledge, confronting oppression, and reordering personal relations and intimacies.

This is the moment that is crucial for constituent politics: the making of a sociomaterial actor on the level of everyday existence, before negotiations about inclusion in existing institutions, expert committees or assemblies are possible. Now, beyond that, imagine a constituent politics approach within STS research that can provide concepts and practices that account for and participate in the making of such an actor. Politics happens when certain human or non-human actors, imperceptible actors, emerge in the technoscientific scene and change the very constitution of being by materialising ordinary relations of justice. Politics is not primarily concerned with contesting given regimes of control by introducing new diversifications of law: that is, rules of equality, the codification of rights and the cultivation of public responsibility. This seems to be a paradoxical proposition since rules of equality, rights and responsibility constitute an indispensable and plausible part of today's forms of active political engagement (and are also at the heart of the formalist, participatory and assembly approaches, and to a certain extent the grounded approach). Rather, politics arises from the emergence of the miscounted, those who have no place and whose capacities remain imperceptible within the normalizing organization of the social realm (Rancière, 1998). Politics is a collective enterprise that exposes a given social order to be limited, contingent and inconsistent by creating an alternative lifeworld inhabited by the previously miscounted.

The aim of this paper was to pose the question: How can we develop an account of constituent politics that is relevant to the specificities of technoscience: a constituent politics that accounts for the remaking of the very substance of being and of life? If technoscience today produces new worlds of existence -- new ontologies -- constituent politics in technoscience is about producing alternative ontologies: alter-ontologies. This involves merging social and material transformations in ways that cannot be simply accommodated within the existing order of a region of objectivity. In fact the whole constituted situation itself needs to be restructured (Rancière, 1998) in order to be able to respond to the alternative ethical, political and material projects that a constituent power puts in motion. Constituent power acts in this sense as a subject (Negri, 1999: 324), but a subject which is not 
external to technoscience itself. Although this subject emerges from within the dynamics of a specific technoscientific field, it, paradoxically, gradually dissolves as a subject and becomes a new form of life that is an alternative social and material way of being. This is what AIDS treatment activists did years before they became political subjects in their own right and constituted a social movement with a distinct profile. Activists created an alternative objectivity, and alter-ontology of existence. How else can we describe the circulation of illegal medications, bodily self-experimentation, the changing of forms of everyday sociability and of sexual intimacy, the militant attacks of political institutions, and the material restructuring of urban spaces? Alter-ontologies go beyond the subject-object dichotomy, not because everything is hybrid or because everything is related to everything else, but because they establish forms of life that are simultaneously the effect and the precondition for the continuation of existence of marginalised actors.

The new social movements of the past decade have increasingly focussed on such socio-material constituent politics. Consider for example the alter-globalisation movement, labour struggles of precarious workers, feminist politics, the new migration movement, radical ecological mobilisations (Bauchspies and Puig de la Bellacasa, 2009; Papadopoulos et al., 2008; Puig de la Bellacasa, 2010a; Samaddar, 2010; Shukaitis et al., 2007). This kind of politics has yet to find clear articulation in the world of technoscience; articulation in the sense of expression but primarily in the sense of recombining existing approaches to politics in new, unexpected ways. Constituent politics in technoscience cannot but emerge out of the different accounts of politics already existing in STS. They draw from the formalist approach its democratic sensibility towards non-contributory experts, from participatory politics its bottom-up citizen perspective on science, from assembly politics the agency of non-humans, and finally from grounded politics -- of which constituent politics are obviously a direct continuation -- the importance of a situated view of complex asymmetrical lifeworlds and the transversality of neglected experiences. At the same time constituent politics evolve from the limitations of these approaches: the neglect of the conflicts which underlie technoscientific controversies in the formalist approach; the reduction of public deliberation to the extent to which given institutions allow participatory politics; the ignorance towards radical divergences which do not comply with relational networks of governance in assembly politics; the reification of the experiences of marginalised actors in early notions of grounded politics.

Making something that is not already given in technoscience, that performs constituent politics in technoscience, is something that, firstly, is concerned with matter and, 
secondly, is necessarily a posthumanist affair. Starting from the latter, posthumanism does not deny human agency, nor does it signify the obsolescence of the human (posthumanism is not about a post-human world); instead, it refers to the complex socio-material constellations in which certain human, non-human others and the biosphere participate equally but differently in the creation of alternative environments of existence (for examples see Puig de la Bellacasa, 2010a). This is an approach to politics that questions the new grand narratives of 'innovation and sustainability' in favour of a more 'humble view of human roles and powers along with a more demanding sense of personal responsibilities' (Winner, 2009) in order to create viable forms of life. This relation to posthumanism is neither about representational politics in a new parliament of things nor about including things as equal others, but about redrawing the material conditions of existence in close cooperation with non-human others in a way that forces the constituted order in a certain region of objectivity to rearrange itself. In an important book Callon and colleagues propose that the posthumanist condition can be dealt with by entering into hybrid forums of negotiation and exchange (Callon et al., 2009). They discuss how actors enter into a new hybrid space of exchange in order to be transformed through this very process of negotiation. However this endeavour proposes (once again) a new representational arena that will foster communication between, and transformation of, the human and non-human actors involved. Constituent politics are less concerned with the creation of such representational spaces. Rather they attempt to create material alliances between particular groups of people (there is no such thing as 'humans') and particular nonhuman others (there is no such thing as the 'non-humans') in order to confront injustice and to make new conditions that ultimately challenge how a certain region of objectivity works. So the first issue for constituent politics is to develop the tools and practices for making cooperative alliances between particular human and non-human groups in order to establish alternative lifeworlds of material justice.

Constituent politics are neither acts of opposition nor of renegotiation of the architectures of power (as Callon et al. propose with their hybrid forums); rather constituent politics attempt to think through and literally make alternative forms of sociability and materiality. Constituent politics in technoscience are inherently transformative and operate immanently on the plane of matter and material justice. The second open question for constituent politics is thus the question of matter and material justice. Constituent politics is a form of politics in technoscience that not only is concerned with knowing but also with careful doing (Haraway, 1997; Puig de la Bellacasa, 2009, 2010b). Crafting alternative readings, new stories of the world, new ways of existing in the world -- all these practices 
coexist on the same plane of action. In this sense constituent politics in technoscience is not just a theory about science and technology but a 'minor science of matter as such' (Deleuze and Guattari, 1987: Ch. 12; for a discussion see Papadopoulos, 2010). Pamela Smith's work shows that artisanal production was crucial for the emergence of the rationalist objectivist scientific word-view which came to dominate the Western world increasingly after the 16th century. It was the artisans' work, an intellectual revolution from the bottom up, that 'transformed the contemplative discipline of natural philosophy into an active one' (Smith, 2006: 239; see also Sennett, 2009). Artisan science was later codified and appropriated into a new disembodied epistemology of experimental science; but experimental science never abandoned artisanal production. In fact experimental sciences always rely on artisanal production and the minor science of matter. It is on the purported modesty of meticulous artisanal efforts that Boyle's bottom-up experimental laboratory science wins over Hobbes' top down geometric science (Shapin and Schaffer, 1985; Haraway, 1997). Rather, what has happened is that experimental science and, to a larger extent today's corporate science, came to obliterate and alienate this artisanal work with matter (Shapin, 2008: 172). The open question for constituent politics is how to re-appropriate the capacity to craft with matter, how to reclaim a science of matter, which, rather than being anchored in a given institution, position, network or subjectivity, creates alternative conditions of existence that make new forms of life emerge: Alter-ontologies.

\section{Notes}

Discussions with Maria Puig de la Bellacasa and her invaluable critical comments made this paper possible. Special thanks go to Harry Collins, Joanna Latimer and Ernst Schraube for their suggestions. The input from presentations of earlier versions of this paper at the Culture, Imagination and Practice Research Group and the Centre for the Study of Knowledge, Expertise and Science at the School of Social Sciences, Cardiff University, the Institute for European Ethnology, Humboldt University in Berlin and the Centre for Philosophy and Political Economy, University of Leicester, and especially the comments from Stefan Beck, Michalis Kontopodis, Steve Brown and Stevphen Shukaitis were crucial for developing the ideas presented here. This paper wouldn't be possible without the collaborations with Niamh Stephenson and Vassilis Tsianos and our common work in earlier publications.

\section{References}

Alcoff L (1998) Epistemology: The Big Questions. Malden: Oxford: Blackwell.

Barry A, Osborne, T and Rose N (1996) Foucault and Political Reason: Liberalism, Neoliberalism, and Rationalities of Government. Chicago: University of Chicago Press. 
Bauchspies W, Puig de la Bellacasa M (guest eds) (2009) Special issue: Re-tooling subjectivities, exploring the possible with feminist science and technology studies. Subjectivity 28.

Bersani L (1987) Is the rectum a grave? October 43: 197-222.

Bevir M, Rhodes, RAW (2003) Interpreting British Governance. London: Routledge.

Bologna S (2006) Die Zerstörung der Mittelschichten: Thesen zur Neuen Selbstständigkeit. Graz: Nausner \& Nausner.

Bracke S, Puig de la Bellacasa M (2009) The arena of knowledge: Antigone and feminist standpoint theory. In: Buikema R and van der Tuin I (eds) Doing Gender in Media, Art and Culture. London: Routledge, 39-53.

Brown P (2007) Toxic Exposures: Contested Illnesses and the Environmental Health Movement. New York: Columbia University Press.

Callon M (1987) Society in the making: The study of technology as a tool for sociological analysis. In: Bijker, WE, Hughes, TP and Pinch, TJ (eds), The Social Construction of Technological Systems: New Directions in the Sociology and History of Technology. Cambridge, Mass.: MIT Press. 83-103.

Callon M, Lascoumes P and Barthe Y (2009) Acting in an Uncertain World: An Essay on Technical Democracy. Cambridge, MA: MIT Press.

Callon M, Rabeharisoa V (2004) Gino's lesson on humanity: Genetics, mutual entanglements and the sociologists role. Economy and Society 33: 1-27.

Callon M, Rabeharisoa V (2008) The growing engagement of emergent concerned groups in political and economic life: Lessons from the French Association of Neuromuscular Disease Patients. Science, Technology, \& Human Values 33(2): 230-261.

Chesters G, Welsh I (2006) Complexity and Social Movements: Multitudes at the Edge of Chaos. London: Routledge.

Chilvers J (2008) Deliberating competence: Theoretical and practitioner perspectives on effective participatory appraisal practice. Science Technology and Human Values 33: 155-85.

Clarke A, Olesen VL (1998). Revisioning women, health and healing : feminist, cultural, and technoscience perspectives. New York: Routledge.

Clifford J (2000) Taking identity politics seriously: 'The contradictory, stony ground ...'. In: Gilroy P, Grossberg L and McRobbie, A (eds.) Without Guarantees: In Honour of Stuart Hall. London ; New York: Verso: 94-112.

Collins HM, Evans R (2007) Rethinking Expertise. Chicago: University of Chicago Press.

Collins HM, Weinel M and Evans, R (forthcoming) The politics of the third wave and elective modernism. Critical Policy Studies.

Davies G (2006) Mapping deliberation: Calculation, articulation and intervention in the politics of organ transplantation. Economy and Society 35: 232-258.

Deleuze G, Guattari F (1987) A Thousand Plateaus: Capitalism and Schizophrenia. Minneapolis: University of Minnesota Press.

EC Commission (2001) European Governance: White Paper. COM(2001) 428 final: Available at: http://europa.eu.int/comm/governance/white_paper/index_en.htm.

Edwards A, Hughes G (2005) Comparing the governance of safety in Europe: A geohistorical approach. Theoretical Criminology 9: 345-63.

Edwards A, Sheptycki J (2009) Third wave criminology: Guns, crime and social order. Criminology \& Criminal Justice, 9(3): 379-97.

Elliott E, Harrop E, and Williams G (2010) Contesting the science: Public health knowledge and action in controversial land-use developments. In: Bennett P and Alman K (eds) Risk, Communication and Public Health. Oxford: Oxford University Press. 
Elliott E, Williams G (2008) Developing public sociology through health impact assessment. Sociology of Health and Illness 30(7): 1101-16.

Epstein S (1995) The construction of lay expertise: AIDS activism and the forging of credibility in the reform of clinical trials. Science Technology and Human Values, 20(4): 408-37.

Epstein S (1996) Impure Science. AIDS, Activism, and the Politics of Knowledge. Berkeley: University of California Press.

Epstein S (2007) Inclusion: The Politics of Difference in Medical Research. Chicago: University of Chicago Press.

Feenberg A (1991) Critical Theory of Technology. New York: Oxford University Press.

Feenberg A (1995) Alternative Modernity: The Technical Turn in Philosophy and Social Theory. Berkeley: University of California Press.

Felt U, Fochler M, Mager A and Winkler P (2008) Visions and versions of governing biomedicine: Narratives on power structures, decision-making and public participation in the field of biomedical technology in the Austrian context. Social Studies of Science 38: 233-258.

Figueroa R, Harding S (eds) (2003) Science and Other Cultures: Diversity in the Philosophy of Science and Technology. New York: Routledge.

Fortun K (2001) Advocacy after Bhopal: Environmentalism, Disaster, New Global Orders. Chicago: University of Chicago Press.

Gorz A (1999) Reclaiming Work. Beyond the Wage-Based Society. Cambridge: Polity Press.

Habermas J (1984) The Theory of Communicative Action. Cambridge: Polity.

Habermas J (1993) Justification and Application. Remarks on Discourse Ethics. Cambridge, MA: MIT Press.

Hall S (1990) Cultural identity and diaspora. In: Rutherford J (ed), Identity: Community, Culture, Difference. London: Lawrence and Wishart, 222-237.

Haraway DJ (1988) Situated knowledges: The science question in feminism and the privilege of partial perspective. Feminist Studies, 14(3): 575-599.

Haraway DJ (1992a) Primate Visions: Gender, Race, and Nature in the World of Modern Science. London: Verso.

Haraway DJ (1992b) The promises of monsters: A regenerative politics for inappropriate/d others. In: Grossberg L, Nelson C and Treichler PA (eds), Cultural Studies. London: Routledge, 295-337.

Haraway DJ (1997) Modest_Witness@Second_Millennium.

FemaleMan`_Meets_OncoMouse ${ }^{\mathrm{TM}}$. Feminism and Technoscience. New York: Routledge.

Harding S (1986) The Science Question in Feminism. Ithaca, NY: Cornell University Press.

Harding S (1991) Whose Science? Whose Knowledge? Thinking From Women's Lives. Ithaca, NY: Cornell University Press.

Harney S (2006) Governance, state, and living labour. Cultural Logic: An Electronic Journal of Marxist Theory and Practice, http://clogic.eserver.org/2006/harney.html, date last accessed: 22.6.2009.

Harney S (2008) Governance and the undercommons. InterActivist, http://slash.autonomedia.org/node/10926, date last accessed: 11.4.2009.

Harrington M (2008) AIDS activists and the people with AIDS. A movement to revolutionize research and for universal access to treatment. In: Da Costa B and Philip K (eds) Tactical Biopolitics: Art, Activism, and Technoscience. Cambridge, MA: MIT, 323340.

Hartsock N (1983) The feminist standpoint: Developing the ground for a specifically feminist historical materialism. In: Harding S and Hintikka M (eds) Discovering Reality: 
Feminist Perspectives on Epistemology, Metaphysics, Methodology and Philosophy of Science. Dordrecht: Reidel, 283-310.

Hess DJ (2004) Special issue: Health, the environment and social movements. Science as Culture 13(4): 421-586.

Hess DJ (2007a) Crosscurrents: Social movements and the anthropology of science and technology. American Anthropologist 109(3): 463-472.

Hess DJ (2007b) Pathways in Science and Industry: Activism, Innovation, and the Environment in an Era of Globalization. Cambridge, MA: MIT Press.

Hubbard R, Henifin MS, Fried B, Druss V and Star, SL (eds) (1979) Women Look at Biology - Looking at Women: A Collection of Feminist Critiques. Cambridge, MA: Schenkman.

Illich I (1979) Tools for Conviviality. London: Fontana.

Irwin A, Michael M (2003) Science, Social Theory and Public Knowledge. Maidenhead: Open University Press.

Jasanoff S (2003) Technologies of humility: Citizen participation in governing science. Minerva 41(3): 223-244.

Latour B (1993) We Have Never Been Modern. Cambridge, MA: Harvard University Press.

Latour B (2003) The promises of constructivism. In Ihde D and Selinger E (eds), Chasing Technoscience: Matrix for Materiality. Bloomington: Indiana University Press, 27-46.

Latour B (2004) Why has critique run out of steam? From matters of fact to matters of concern. Critical Inquiry 30(2): 225-248.

Latour B (2005a) From realpolitik to dingpolitik or how to make things public. In Latour B and Weibel P (eds), Making Things Public: Atmospheres of Democracy. Cambridge, MA: MIT Press, 4-31.

Latour B (2005b) Reassembling the Social: An Introduction to Actor-Network-Theory. Oxford: Oxford University Press.

Latour B (2007) Turning around politics: A note on Gerard de Vries' paper. Social Studies of Science 37: 811-820.

Law J (1999) After ANT: Complexity, naming and topology. In Law J and Hassard J (eds), Actor Network Theory and After. Oxford: Blackwell, 1-14.

Law J (2004) After Method: Mess in Social Science Research. London: Routledge.

Leach M, Scoones I, and Wynne B (eds) (2005) Science and Citizens: Globalization and the Challenge of Engagement. London: Zed.

Lengwiler M (2008) Participatory approaches in science and technology: Historical origins and current practices in critical perspective. Science Technology, \& Human Values 33: $186-200$.

Liberatore A, Funtowicz S (2003) Introduction: 'Democratising' expertise, 'expertising' democracy: what does this mean, and why bother? Science and Public Policy, 30(3): 146-150.

Longino HE (2002) The Fate of Knowledge. Princeton: Princeton University Press.

MacIntyre A (1981) After Virtue: A Study in Moral Theory. Notre Dame, IN: University of Notre Dame Press.

Malos E (ed) (1980) The Politics of Housework. London: Allison and Busby.

Marazzi C (1998) Der Stammplatz der Socken. Die linguistische Wende der Ökonomie und ihre Auswirkungen in der Politik. Zürich: Seismo Verlag.

Marcuse H (1991) One-Dimensional Man: Studies in the Ideology of Advanced Industrial Society. London: Routledge.

Mol A (2002) The Body Multiple: Ontology in Medical Practice. Durham: Duke University Press. 
Moulier Boutang Y (1998) De L'esclavage au Salariat. Economie Historique du Salariat Bridé. Paris: Presses Universitaires de France.

Munro R, Mouritsen J (eds) (1997) Accountability: Power, Ethos, and the Technologies of Managing. Boston: International Thomson Business Press.

Negri A (1999) Insurgencies: Constituent Power and the Modern State. Minneapolis: University of Minnesota Press.

Negri A (2005) The Politics of Subversion: A Manifesto for the Twenty-first Century. Cambridge: Polity.

Neyland D, Woolgar S (2002) Accountability in action? The case of a database purchasing decision. British Journal of Sociology 53(2): 259-274.

Nowotny H, Rose H (1979) Counter-Movements in the Sciences: The Sociology of the Alternatives to Big Science. Dordrecht: Reidel.

Nowotny H, Scott P, and Gibbons M (2001) Re-thinking Science: Knowledge and the Public in an Age of Uncertainty. Cambridge: Polity.

Panzieri R, Sohn-Rethel A, Palloix C, Bologna S, and Tronti M (1976). CSE Pamphlet No. 1: The Labour Process \& Class Strategies. London: Conference of Socialist Economists.

Papadopoulos D (2006) World 2: On the significance and impossibility of articulation. Culture, Theory and Critique 47(2): 165-179.

Papadopoulos D (2010). Activist Materialism. Deleuze Studies (in press).

Papadopoulos D, Stephenson N (2007) Traveling experience: Rethinking the limits of empirical evidence in social science. In: Van Deventer V, Terre Blanche M, Fourie M, and Segalo P (eds) Citizen City: Between Constructing Agent and Constructed Agency. Toronto: Captus, 128-137.

Papadopoulos D, Stephenson N and Tsianos V (2008) Escape Routes: Control and Subversion in the 21 st Century. London: Pluto Press.

Puig de la Bellacasa M (2009) Power to touch: The remaking of sensual experience and the politics of speculative constructivism. Subjectivity 28: 297-315.

Puig de la Bellacasa M (2010a) Ethical doings in naturecultures. Ethics, Place and Environment 13(3): ??- ??.

Puig de la Bellacasa M (2010b). Matters of care in technoscience: Assembling neglected things. Social Studies of Science 40(6): ???-???.

Rancière J (1998) Disagreement: Politics and Philosophy. Minneapolis: University of Minnesota Press.

Rapp R (2000) Testing Women, Testing the Fetus: The Social Impact of Amniocentesis in America. New York: Routledge.

Ravetz JR (1990) The Merger of Knowledge with Power: Essays in Critical Science. London: Mansell.

Ravetz JR (2006) The No-Nonsense Guide to Science. Oxford: New Internationalist.

Rawls J (1971) A Theory of Justice. Cambridge, MA: Belknap Press.

Rhodes RAW (1997) Understanding Governance: Policy Networks, Governance, Reflexivity and Accountability. Buckingham: Open University Press.

Rose H (1994) Love, Power and Knowledge. Cambridge: Polity Press.

Rose H, Rose S (1969) Science and Society. London: Penguin.

Rosenau JN, Czempiel EO (1992) Governance Without Government: Order and Change in World Politics. Cambridge: Cambridge University Press.

Rowe G, Frewer LJ (2004) Evaluating public-participation exercises: A research agenda. Science Technology and Human Values 29: 512-557.

Samaddar R (2010) Emergence of the Political Subject. New Delhi: Sage.

Sandoval C (1991) U.S. third world feminism: The theory and method of oppositional consciousness in the postmodern world. Genders 10: 1-24. 
Scanlon T (1998) What We Owe to Each Other. Cambridge, MA: Harvard University Press. Scott JW (1991) The evidence of experience. Critical Inquiry 17(4): 773-797.

Sennett R (2009) The Craftsman. London: Penguin.

Shapin S (2008) The Scientific Life: A Moral History of a Late Modern Vocation. Chicago: University of Chicago Press.

Shapin S, Schaffer S (1985) Leviathan and the Air-Pump: Hobbes, Boyle, and the Experimental Life. Princeton: Princeton University Press.

Shiva V (2006) Earth Democracy: Justice, Sustainability and Peace. London: Zed.

Shukaitis S, Graeber D, Biddle E (2007) Constituent Imagination: Militant Investigations, Collective Theorization. Oakland, CA: AK Press.

Smith MR, Marx L (eds) (1994) Does Technology Drive History? The Dilemma of Technological Determinism. Cambridge, MA: MIT Press.

Smith PH (2006) The Body of the Artisan: Art and Experience in the Scientific Revolution. Chicago: University of Chicago Press.

Star SL (1991) Power, technologies and the phenomenology of conventions: On being allergic to onions. In: Law J (ed) A Sociology of Monsters: Essays on Power, Technology and Domination. London: Routledge, 26-56.

Stengers I (2005) The cosmopolitical proposal. In: Latour B and Weibel P (eds), Making Things Public: Atmospheres of Democracy. Cambridge, MA: MIT Press, 994-1003.

Stengers I (2008) A constructivist reading of process and reality. Theory Culture and Society 25: $91-110$.

Stephenson N (2003) Interrupting neo-liberal subjectivities. Continuum: Journal of Media and Cultural Studies 17(2): 135-146.

Stephenson N, Papadopoulos D (2006) Analysing Everyday Experience: Social Research and Political Change. London: Palgrave Macmillan.

Strathern M (2005) Kinship, Law and the Unexpected: Relatives are Always a Surprise. Cambridge: Cambridge University Press.

Taylor C (1986) Sprache und Gesellschaft. In: Honneth A and Joas H (eds), Kommunikatives Handeln. Frankfurt/M.: Suhrkamp, 35-52.

Taylor C (1991) The Malaise of Modernity. Concord: Anansi.

Turner SP (2003) Liberal Democracy 3.0: Civil Society in an Age of Experts. London: Sage.

Webster A (2007) Crossing boundaries: Social science in the policy room. Science Technology, \& Human Values 32: 458-478.

Weinel M (2007) Primary source knowledge and technical decision-making: Mbeki and the AZT debate. Studies in History and Philosophy of Science 38(4): 748-760.

Wellmer A (1977) Kommunikation und Emanzipation. Überlegungen zur »sprachanalytischen Wende « der kritischen Theorie. In: Jaeggi U and Honneth A (eds) Theorien des Historischen Materialismus. Frankfurt/M.: Suhrkamp, 465-499.

Welsh I, Plows A, and Evans R (2007) Human rights and genomics: Science, genomics and social movements at the 2004 London Social Forum. New Genetics and Society 26(2): 123-135.

Whitehead AN (1979) Process and Reality: An Essay in Cosmology. New York: Free Press.

Wimmer R (1980) Universalisierung in der Ethik. Analyse, Kritik und Rekonstruktion ethischer Rationalitätsansprüche. Frankfurt/M.: Suhrkamp.

Winner L (1986) The Whale and the Reactor: A Search for Limits in an Age of High Technology. Chicago: University of Chicago Press.

Winner L (1993) Upon opening the black box and finding it empty: Social constructivism and the philosophy of technology. Science Technology, \& Human Values 18(3): 362-378. 
Winner L (2009) Mega-narratives of scientific technology: A time of crisis. Unpublished manuscript, Department of Science and Technology Studies, Rensselaer Polytechnic Institute.

Wittgenstein L (1958) Philosophical Investigations. Oxford: Blackwell.

Woodhouse E, Hess,DJ, Breyman S, and Martin B (2002) Science studies and activism: Possibilities and problems for reconstructivist agendas. Social Studies of Science 32(2): 297-320.

Wynne B (2003) Seasick on the third wave? Subverting the hegemony or propositionalism: Response to Collins and Evans (2002). Social Studies of Science 33(3): 401-418.

Wynne B (2005) Reflexing complexity: Post-genomic knowledge and reductionist returns in public science. Theory Culture and Society 22(5): 67-94.

\section{Biographical Note}

Dr. Dimitris Papadopoulos teaches politics, organisation and culture at the School of Management, University of Leicester. His work on social and political theory, experience and subjectivity, labour and social transformation has appeared in various journals including Boundary 2; Culture, Theory \& Critique; Darkmatter; British Journal of Social Psychology; and Ephemera. He has published numerous books, including, most recently, two co-authored monographs: Escape Routes. Control and Subversion in the $21^{\text {st }}$ Century (Pluto Press, 2008) and Analysing Everyday Experience: Social Research and Political Change (Palgrave, 2006). He is currently working on the Politics of Matter: Ontology and Justice after Constructivism, a study of matter, materialism, and radical interventions in technoscience. He is co-editor of the journal Subjectivity. 